\title{
KEPUASAN DAN LOYALTAS PELANGGAN PADA PRODUK SUSU BAYI MENGGUNAKAN SERVICE QUAUTY DAN PATH ANALYSIS
}

\author{
Kukuh Winarso* \\ Universitas Trunojoyo
}

\begin{abstract}
To enlarge market share a company has to produce quality product, accordance with what the consumers want. At the large step company has to be able to see and give more attention to the customer (consumer) satisfaction factors. In the next steps company can identify their customer loyalty to their products, that are factors or variables influence consumers loyalty to select to buy their products. There are many factors that can identify whether the consumer is loyal or not, such as by knowing the characteristics of a loyal consumer : a) buy regularly, b) buy outside the product line, c) refuse other products and show resistance from competitors power of attraction (not ea sily influenced by competitors power of attraction for the same products), d) recommend from mouth to mouth. Included in this research is PT. $X$ that produce baby milk, needs approaches to identify satisfaction and finally customers loyalty. The results of this research show that consumers percieve service quality they received as not yet fulfill their expectations. Improvement priority should be started from Responsiveness, Emphaty, Assurance, Tangible and Reliability dimensions. All consumer satiffaction dimensions, both directly or simultaneously influence to consumers loyalty. Consumer satiffaction for Tangible, Reliability, Responsiveness, Assurance and Emphaty dimensions together influence to consumer loyalty of $54.66 \%$. Whereas other variablesinfluenc es outside the service quality dimension to consumer loya lty of $45.34 \%$
\end{abstract}

Keyword : Market, Product Quality, Satisfaction, Loyalty and Service Qua lity

\section{PENDAHULUAN}

Peramal atau prediktor terbaik mengenai pertumbuhan yang dilakukan oleh manajemen dapat ditangkap hanya dari sebuah pertanyaan quisioner: Bagaimana konsumen memberikan rekomendasi kepada temannya terhadap perusahaan dan produk. Temuan ini adalah hasil dari dua tahun riset yang dilakukan pada survey (Reicheld, 2003) dengan bermacam-macam pertanyaan yang telah diajukan pada prilaku konsumen (pada saat membeli) dan pada akhimya berhubungan dengan pertumbuhan perusahaan. Anehnya, pertanyaan yang paling effektif bukan tentang kepuasan pelanggan atau loyalitas pelanggan. Yang paling penting adalah persentase dari konsumen yang cukup antusias 
terhadap sebuah perusa haan dan produk untuk disampaikan pada temannya a tau kolega yang langsung berhubungan dengan tingkat pertumbuhan diantara para kompetitomya. Kesediaan untuk menyampaikan suatu produk dari perusahaan ini pada teman, keluarga dan kolega adalah salah satu indikator terbaik untuk mengukur loyalitas, karena pengorbanan konsumen dalam membuat rekomendasi ini yang tanpa ada yang membayamya. Pada saat konsumen memberikan petunjuk/rekomendasi (referensi), pada dasamya konsumen mengindikasikan telah menerima lebih nilai ekonomi dari sebuah barang dari penusahaan. Konsumen telah mempertaruhkan reputasi dininya. poin penting dari survey ini adalah hal baru, pendekatan sederhana pada riset konsumen yang secara langsung berhubungan dengan hasil yang dic apai perusahaan

Menurut Kotler dan Amstrong (1997), apabila pelanggan merasa puas terhadap kinerja bauran pemasaran produk, maka pelanggan akan melakukan pembelian ulang, bahkan lebih jauh lagi mereka akan melakukan promosi mulut ke mulut kepada rekan, saudara, a tau kenalan terdeka tnya agarmengguna kan produk yang sama (rekomendasi).

Konsumen loyal a dalah suatu a set yang tak temilai bagi penusa ha an karena ka ra kteristik da ri konsumen yang loyal antara lain meliputi :

a. Melakukan pembeli secara teratur

b. Menolak produk lain

c. Menunjukan kekebalan dari daya tarik pesaing

\section{Penumusan masalah}

Berdasarkan latar bela kang yang a da, maka dapat dinumuskan suatu pema salahan, yaitu :

1. Sejauh mana kepuasan konsumen yang dapat menjadikan konsumen loyal terhadap produk susu bayi dari PT. X.

2. Atribut apa saja yang perlu dipertahankan atau ditingkatkan sebagai usaha untuk meningkatka $n$ loyalitas pelanggan.

3. Bagaimana improvement yang dilakukan oleh PT. X untuk menjawab dua permasalahan diatas.

\section{Tujuan Penelitian}

Penelitian ini bertujuan untuk menjawab pokok permasalahan yang telah disampaikan diatas, dan secara spesifik dapat disebutkan sebagai berikut : 
1. Menganalisa atribut-atribut pada produk susu bayi yang menjadikan seorang pelanggan menjatuhkan pilihannya pada produk PT. X

2. Mengetahui prioritas perbaikan dimensi-dimensi Service Quality untuk meningkatkan kepuasan konsumen

3. Mengetahui atribut-atribut pada produk, sebagai upaya untuk menjaring loyalitas pelanggan

\section{KAJ IAN PUSTAKA DAN PENG EMBANGAN HIPOTESS}

\section{Pandangan Tentang kepuasan Pelanggan}

Definisi kepuasan pelanggan adalah perasaan senang atau kecewa seseorang yang muncul setelah membandingkan antara persepsi terhadap kineja (performance) suatu produk dan harapan-harapannya (Kotler,2000). Kepuasan merupakan fungsi dari persepsi atas kineja dan harapan. Jika kineja melebihi harapan pelanggan amat puas atau senang. Banyak perusahaan memfokuskan pada kepuasan tinggi karena pelanggan yang tingkat kepuasannya sedang-sedang saja, akan mudah untuk berubah pikiran apabila mendapat tawaran yang lebih baik. Tingkat kepuasan yang tinggi akan menciptakan kelekatan emosional terhadap merek tertentu, hasilnya adalah kesetiaan pelanggan yang sangat tinggi.

Dalam penelitian pendahuluan di PT. X, melakukan pendekatan terhadap konsumen dengan melihat sampai dimana kepuasan pelanggan itu tercapai yang pada akhimya akan menimbulkan terja dinya loyalitas terhadap produk susu tersebut. Loyalitas diukur dari seberapa besar pengorbanan konsumen dalam kesetiaanya akan produk ini pada saat yang sama juga tersedia produk sejenis di pasaran. Kondisi pasar dengan aneka produk baik sejenis maupun tidak sejenis semakin menunjukkan menununnya keinginan konsumen akan produk tersebut, artinya konsumen sudah mencapai titik jenuh dan bingung karena terlalu banyak informasi yang beredar di berbagai media melalui iklannya, maka bentukbentuk promosi Word-of-Mouth (rekomendasi) akan semakin penting bagi perusahaan (Ka rtajaya, 2004).

Parasuraman (1990) merumuskan suatu model kulitas suatu produk yang menentukan pada persayaratan utama bagi penyedia produk dalam memberikan kualitas produk yang diharapkan konsumen. Ada lima model gap yang dapat menyebabkan kegagalan produsen dalam memberikan produknya pada konsumen :

1. Gap I, antara harapan konsumen dan persepsi manajemen, karena pihak manajemen tidak mengetahui apa yang di harapkan oleh konsumen secara tepat. 
2. Gap II, antara persepsi manajemen terhadap harapan konsumen \& spesifikasi kualitas produk karena adanya penyimpangan da la m penetapan spesifikasi kualitas produk.

3. Gap III, antara spesifikasi kualitas produk dan penyampaian produk karena adanya ketidaksesuaian antara spesifikasi kualitas produk yang ditetapkan dengan performansi produk yang diberikan.

4. Gap IV, antara penyampaian produk \& komunikasi ekstemal, terjadi karena apa yang dijanjikan penyedia produk tidak sesuai dengan pelaksanaannya

5. Gap V, antara produk yang diterima dan diharapkan atas produk tersebut, tejadi karena satu atau beberapa gab diatas terja di.

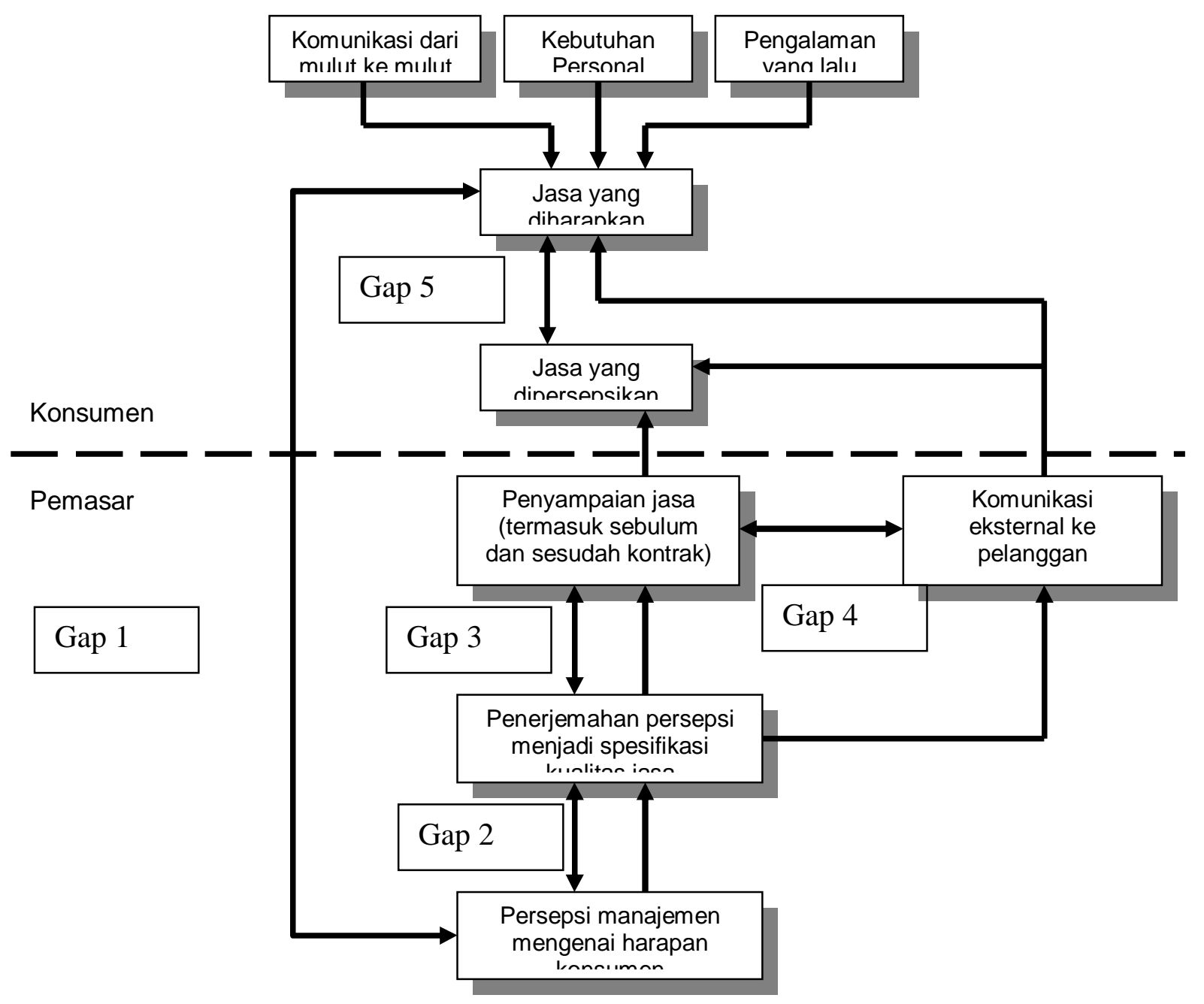

Gambar 1. Skema Gab Produsen dan Konsumen

\section{Ekpektasi Pelanggan}

Ekspektasi pelanggan adalah keyakinan tentang penghantaran produk/jasa yang berfungsi sebagai standar atau titik referensi dalam bertindak, dimana performansi sebagai 
pertimbangan. Rust, Zahorik dan Keiningham (1996) menyatakan bahwa tingkat ekspektasi pelanggan dapat dibagi atas:

1. Will Expectation, merupakan tingkat rata-rata dari kualitas yang diprediksi berdasarkan semua informasi yang diketahui. Ini merupakan tingkat ekspektasi yang sering diartikan oleh konsumen dan peneliti. Ketika konsumen mengatakan "produk/jasa ini telah memenuhi keinginan saya", berarti produk/jasa ini lebih baik dari apa yang mereka prediksi a kan terja di.

2. Should Expectation, merupakan apa yang pelanggan rasakan sepantasnya mereka terima dari transaksi. Sangat sering apa yang mereka rasakan seharusnya tejadi lebih baik dari apa yang mereka pikirkan akan terjadi.

3. Ideal Expectation, adalah apa yang akan terjadi dalam keadaan yang terbaik. Ini berguna sebagai barometer dari kesempumaan.

\section{Persepsi Pelanggan}

Persepsi pelanggan lebih mengacu pada persaan pelanggan temadap produk/jasa yang ia terima berdasarkan apa yang ia bayangkan akan ia terima. Apabila ia merasa produk/jasa yang ia terima seperti atau melebihi yang ia bayangkan, ia akan merasa puas dan kualitas produk/jasa perusahaan akan dipersepsikan tinggi. Sebailknya jika ia merasa tidak seperti yang ia harapkan maka akan terjadi ketidakpuasan dan kualitas produk/jasa akan dipersepsikan rendah. Tidak semua persepsi pelanggan adalah benar, apabila pelanggan mempersepsikan bahwa suatu produk/jasa adalah jelek, mungkin saja secara objektive sudah bagus, maka perusahaan sebagai penyedia produk/jasa seharusnya dapat mengendalikan dan mengantisipasi terhadap kemungkinan persepsi jelek atau keluhan yang seharusnya tidak terjadi. Penusahaan juga senantiasa peka dan selektif terhadap semua keluhan dan informasi yang disampaika pelanggan

\section{Loyalitas Pelanggan}

Memiliki konsumen yang loyal adalah tujuan semua perusahan. Loyalitas pelanggan adalah proporsi seberapa sering seorang pembeli memilih produk atau pelayanan yang sama dalam suatu kategori tertentu dibandingkan dengan jumlah pembelian keselunuhan dalam kategori yang sama dengan kondisi tersedianya pilihan produk/jasa yang lain pada kategor tersebut (Neal,1999). Sedangkan Oliver (1996) menyatakan bahwa loyalitas pelanggan adalah komitmen yang mendalam dari konsumen untuk melakukan pembelian ulang terhadap produk atau jasa tertentu secara konsisten dimasa yang akan datang. Konsumen yang loyal merupakan asset tak temilai bagi perusahaan karena karakteristik dari konsumen 
yang loyal antara lain: (1) melakukan pembelian secara teratur, (2) membeli diluar lini produk/jasa, (3) menolak produk lain dan (4) menunjukkan kekebalan daya tarik pesaing (tidak mudah terpengaruh oleh daya tarik produk sejenis dari pesaing).

\section{Kualitas Pelayanan}

kualitas jasa atau kualitas pelayanan dapat didefinisikan sebagai tingkat ketidakcocokan antara ekspektasi a ta u keinginan konsumen dan persepsi konsumen (Zethaml, Parasuraman dan Berry, 1980). Mereka menyatakan ada 10 dimensi yang diperlukan pelanggan untuk menilai kualitas, antara lain Tangible (hal-hal yang benjud), Reliability (keandalan), Responsiveness (cepat tanggap), Competence (kopetensi), Courtesy (kesopanan), Credibility (kredibilitas), Communication (komunikasi), Security (keamanan), Acces (akses), Understanding The Customer (memahami pelanggan).

Dari kesepuluh dimensi pelayanan tersebut dikelompokan menjadi lima dimensi ServQual :

1. Tangible, penampilan dari fisik, desa in, ha rga dsb.

2. Reliabilitas, (Keandalan), kemampuan dari para tenaga penjual untuk membantu pembeli (konsumen) secara tepat, akurat dan memuaskan, komposisi dan kandungan yang tertera di produk sesuai dengan yang dija njikan, mudah didapat dipasaran.

3. Responsiveness, (daya tanggap), yaitu memberikan produk sesuai dengan yang dibutuhkan oleh konsumen, dibukanya kotak aduan melalui telepon bebas pulsa bagi setiap konsumen.

4. Assurance, (jaminan), meliputi kepastian masa kedaluarsa produk, bebas dari efek samping yang buruk bagi konsumen.

5. Emphaty (empati), perhatian dari produsen terhadap kebutuhan pelanggan (konsumen), pelayanan puma jual.

\section{Metode Kepuasan Pelanggan}

\section{Senvice Quality (Senqual)}

Metode SERVQUAL yang dikembangkan oleh Zeithaml (1991) adalah salah satu metode nyang digunakan untuk mengukur kualitas jasa. Pengukuran dengan metode ini menggunakan elemen-elemen yang terdapat dalam jasa. Mutu jasa diukur secara kuantitatif dalam bentuk kuesioner yang item-item pertanyaannya berasal dari dimensidimensi mutu jasa. Dimensi mutu jasa yang digunakan dalam metode ini adalah lima dimensi mutu jasa ya itu tangibles, reability, responsiveness, assurance dan emphaty. 
Metode SERVQUAL terdin atas 2 bagian ya itu:

1. Bagian ekspektasi, yang memuat pemyataan-pemyataan untuk mengetahui dengan pasti ekspekta si umum dari konsumen terhadap sebuah jasa.

2. Bagian persepsi, yang memuat pemyataan-pemyataan untuk mengukur persepsi konsumen terhadap perusahaan tertentu dengan ka tegori tertentu.

Pengukuran terhadap kualitas jasa dengan menggunakan metode SERVQUAL melibatkan perbedan penilaian konsumen pada pasangan pemyatan persepsi-ekspektasi. Secara spesifik, skor SERVQUAL untuk setiap pasangan penyataan untuk setiap konsumen dihitung sebagai: Skor Persepsi - Skor Ekspektasi

\section{Path Analysis (Analisa J alur)}

Salah Satu tujuan penelitian adalah untuk mengungkapkan hubungan antar variabel. Masalahanya adalah pola hubungan yang bagaimana yang ingin diungkapkan. Apakah pola hubungan yang diarahkan untuk menduga atau membuat peramalan, yang analisisnya disebut analisa regresi, atau pola hubungan yang memperlihatkan eratnya hubungan antara variabel-variabel, yang analisisnya disebut analisis korelasi, atau pola hubungan yang mengungkapkan pengaruh sebuah variabel atau seperangkat variabel terhadap sebuah variabel lainnya, baik pengaruh langsung maupun tidak langsung dan a na lisisnya disebut a na lisa jalur (Path Analysis)

Pola Hubungan yang mengungkapkan pengaruh sebuah variabel dengan variabel lain, baik pengaruh langsung maupun tidak langsung. Analisis ini dikembangkan oleh Wright (1934) dengan tujuan menerangkan akibat langsung dan tidak langsung seperangkat variabel, sebagai variabel penyebab, terhadap variabel lainnya yang merupakan variabel penyebab. Analisa jalur berguna untuk menguji hubungan sebab akibat tersebut. Langkah untuk membuat a na lisis jalur a dalah sebagai berikut :

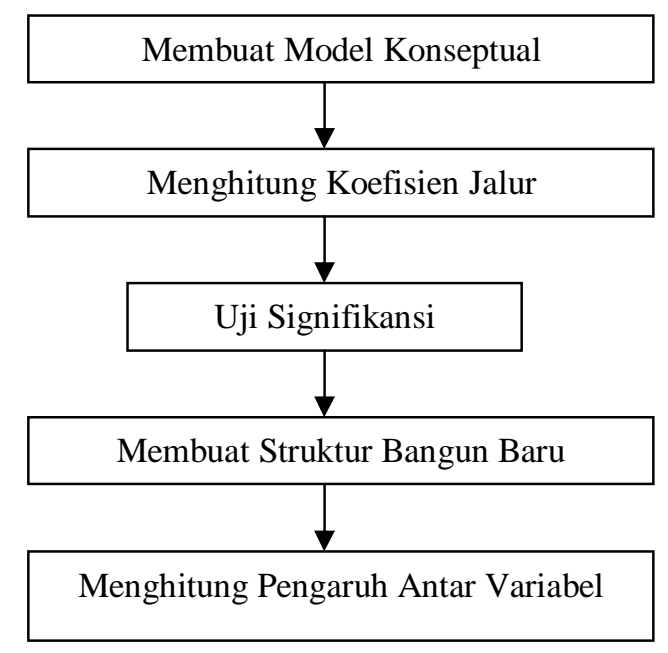


Gambar 2.2. Tahapan Proses Ana lisisJ alur

\section{Ufi Validitas dan Reliabilitas}

Agar keakuratan dari a pa yang diukur itu menja di semakin baik maka diperlukan suatu alat ukur yaitu dengan menggunkan uji validasi. Uji validasi ini menggunakan teknik a na lisis item, yaitu mengetahui konsistensi anta ra skor item dengan skor keseluruhan. Konsistensi tersebut dapat dilihat pada koefisien korelasi antar item dengan skor keseluruhan. Korelasi ini menggunakan Product Moment Pearson :

$$
\mathrm{r}=\frac{\sum \mathrm{xy}-\left(\sum \mathrm{xy}\right)\left(\sum \mathrm{y}\right)}{\sqrt{\left\{\sum \mathrm{x}^{2}-\frac{\left(\sum \mathrm{x}\right)^{2}}{\mathrm{n}}\right\}\left\{\sum \mathrm{y}^{2}-\frac{\left(\sum \mathrm{y}\right)^{2}}{\mathrm{n}}\right\}}}
$$

dimana :

$r$ : Koefisien korelasi Pearson

$x$ : Skor setiap item instrumen

$y$ : Skor total item instrumen

$n$ : ukuran sampel

Sementara menguji keberartian koefisien korelasi menggunakan uji t, dengan rumus:

$$
\mathrm{t}=\frac{\mathrm{r} \sqrt{(\mathrm{n}-2)}}{\sqrt{1-\mathrm{r}^{2}}} ; \mathrm{db}=\mathrm{n}-2
$$

Dengan keputusan hipotesa, yaitu item pertanyaan instrumen penelitian adalah valid

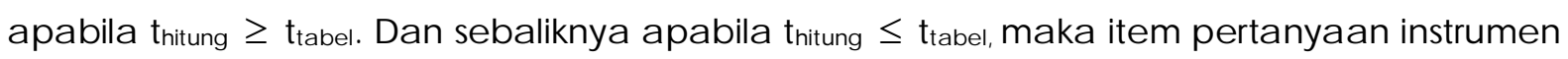
penelitian tidak valid. Untuk uji reliabilitas dengan menggunakan teknik split - half dari Speaman Brown dan koefisien Alpha Cronbach. Metode split - half dengan melakukan pembelahan item-item instrumen menjadi dua kelompok (ganjil dan genap), kemudian dilakukan perhitungan jumlah skor total masing-masing belahan untuk setiap responden. Nilai skor kelompok ganjil dan genap kemudian dicari koefisien korelasi dan tingkat reliabilita snya, yaitu menggunakan rumus:

$$
r_{i}=\frac{2 r_{b}}{1+r_{b}}
$$

dimana : $\quad r_{i}$ : Reliabilitas intemal seluruh item

$$
r_{b} \text { : Korelasi antar belahan pertama dengan belahan kedua }
$$


Jurnal Manajemen Teori dan Terapan | Tahun 3, No.1, April 2010 | Kukuh Winarso 
Sementara itu penghitungan koefisien Alpha Cronbach $(\alpha)$ adalah dengan rumus:

$$
\alpha=\frac{\mathrm{k} \overline{\mathrm{r}}}{1+(\mathrm{k}-1) \overline{\mathrm{r}}}
$$

dimana : $\quad \alpha$ : Koefisien keandalan alat ukur

$\bar{r}$ : Rata-rata korelasi antarvariabel manifes

$\mathrm{k}$ : J umlah variabel manifes yang membentuk variabel laten

Dengan keputusan hipotesa, yaitu jika koefisien reliabilitas intemal seluruh item $\left(r_{i}\right) \geq$ rtabel maka keputusannya adalah item instrumen dinyatakan reliabel. Dan sebaliknya apabila ( $r_{i}$ ) $\leq$ rabel, maka item instrumen penelitian tidak reliabel.

\section{Mengukur Servqual}

Metode Servqual dilakukan pada pengolahan data dengan tujuan untuk mengukur dimensi-dimensi servqual pada susu bayi dari PT X dan produk susu lainnya. Adapun cara menghitung nilai servqual a dalah :

1. Tentukan nilai Servqual (S) bagi setiap pemyataan setiap responden, dengan persamaan :

$S_{i}=P_{i}-E_{i} ; i: 1,2,3 \ldots . . n$

Dimana : $\mathrm{P}_{\mathrm{i}}$ : Nilai persepsi responden untuk pertanyaan ke-i

$\mathrm{E}_{\mathrm{i}}$ : Nilai ekspektasi responden untuk pertanyaan ke-i

2. Nilai servqual yang didapat dari setiap dimensi untuk tiap responden dijumlahkan. Kemudian dibagi dengan banyaknya pertanyaan yang mewakili dimensi tersebut, seperti rumus berikut:

$$
S K=\frac{\sum_{i=1}^{n} S_{i}}{x}
$$

dimana :

SK : Skor (nilai) rata-rata untuk setiap dimensi

$\mathrm{S}$ : Nila i servqual setia $\mathrm{p}$ pertanyaan

$\mathrm{x}$ : Banyaknya pertanya an yang mewa kili dimensi tersebut

3. Nilai SKi dikalikan dengan nilai bobot $\left(w_{i}\right)$ yang dialokasikan untuk kreteria tersebut sehingga didapat nilai sevqual terbobot $\left(\mathrm{SQ}_{\mathrm{i}}\right)$ untuk kreteria tersebut bagi setiap responden, dengan persamaan :

$$
\mathrm{SQ}_{\mathrm{i}}=\sum_{\mathrm{i}=1}^{\mathrm{n}} \mathrm{SK}_{\mathrm{i}} \mathrm{w}_{\mathrm{i}} \quad ; \mathrm{i}: 1,2,3 \ldots \mathrm{n}
$$


4. Nilai SQi dijumlahkan untuk mendapatkan nilai total servqual (TSQ) bagi setiap responden, persama annya :

$$
\mathrm{TSQ}=\sum_{\mathrm{i}=1}^{\mathrm{n}} \mathrm{SQ}_{\mathrm{i}} \quad ; \mathrm{i}: 1,2,3 \ldots \mathrm{n}
$$

5. Nilai rata-rata servqual diperoleh dengan membagi TSQ dengan $\mathbf{N}$ (jumlah responden), seperti persamaan :

$$
\overline{\mathrm{TSQ}}=\frac{\mathrm{TSQ}}{\mathrm{N}}
$$

Pembobotan $\left(\mathrm{W}_{\mathrm{i}}\right)$ seperti ditunjukan pada langkah ketiga diatas adalah dengan metode pembobotan rata-rata (Weighted Average Methode). Pembobotan ini sering digunakan pada prosedur perbandingan, dimana dengan multiple decision making yang digunakan untuk rating dan memilih altematif dengan membuat urutan yang lebih disukai berdasarkan pada rating pada kreteria yang dipertimbangkan. Misal, $w_{i}: i=1,2,3 \ldots . m$ adalah bobot setia $\mathrm{p}$ kreteria dan $\mathrm{r}_{\mathrm{ij}}$ adalah nila i numerik pada kreteria i dan altematif j, maka nilai altematif j dinyatakan :

$$
\begin{aligned}
& \mathrm{U}_{\mathrm{j}}=\sum_{\mathrm{i}=1}^{\mathrm{m}} \mathrm{w}_{\mathrm{i}} \mathrm{r}_{\mathrm{ij}} \text { altema tif terbaik adalah dengan melihat nilai altema tif terbesar, yaitu : } \\
& \mathrm{U}_{\text {optimal }}=\underset{\text { semua }}{\max } \mathrm{U}_{\mathrm{j}}
\end{aligned}
$$

Pengambilan keputusan yang berkaitan dengan fungsi utilitas multiatribut, menggunakan dua asumsi, yaitu :

1. Fungsi utilita sdengan a tributnya adalah linier, ya itu :

$$
U\left(r_{i j}\right)=a_{i}+b_{i} r_{i j} \text {, dimana } b_{i}>0
$$

2. Total utilitas untuk altematif $j, U_{j}$ menupakan fungsi penjumlahan dari $U\left(r_{i j}\right)$, yaitu :

$$
\mathrm{U}_{\mathrm{j}}=\sum_{\mathrm{i}=1}^{\mathrm{m}} \mathrm{u}\left(\mathrm{r}_{\mathrm{ij}}\right)
$$

Kemudian didapatkan :

$$
\mathrm{U}_{\mathrm{j}}=\sum_{\mathrm{i}=1}^{\mathrm{m}} \mathrm{a}_{\mathrm{i}}+\sum_{\mathrm{i}=1}^{\mathrm{m}} \mathrm{b}_{\mathrm{i}} \mathrm{r}_{\mathrm{ij}}
$$

karena $\sum_{\mathrm{i}=1}^{\mathrm{m}} \mathrm{a}_{\mathrm{i}}$ memiliki nilai yang sama untuk semua altematif, sehingga satu-satunya parameter yang dipertimbangkan dalam peringkingan $n$ altematif adalah bobotnya, $b_{i}, i=$ $1,2,3 \ldots \mathrm{m}$ 


\section{Mengukur Penganuh Kepuasan Konsumen Terhadap Loyalitas Konsumen}

Proporsi yang diajukan oleh peneliti diterjema hkan keda la m diagra m jalur seba gai berikut :

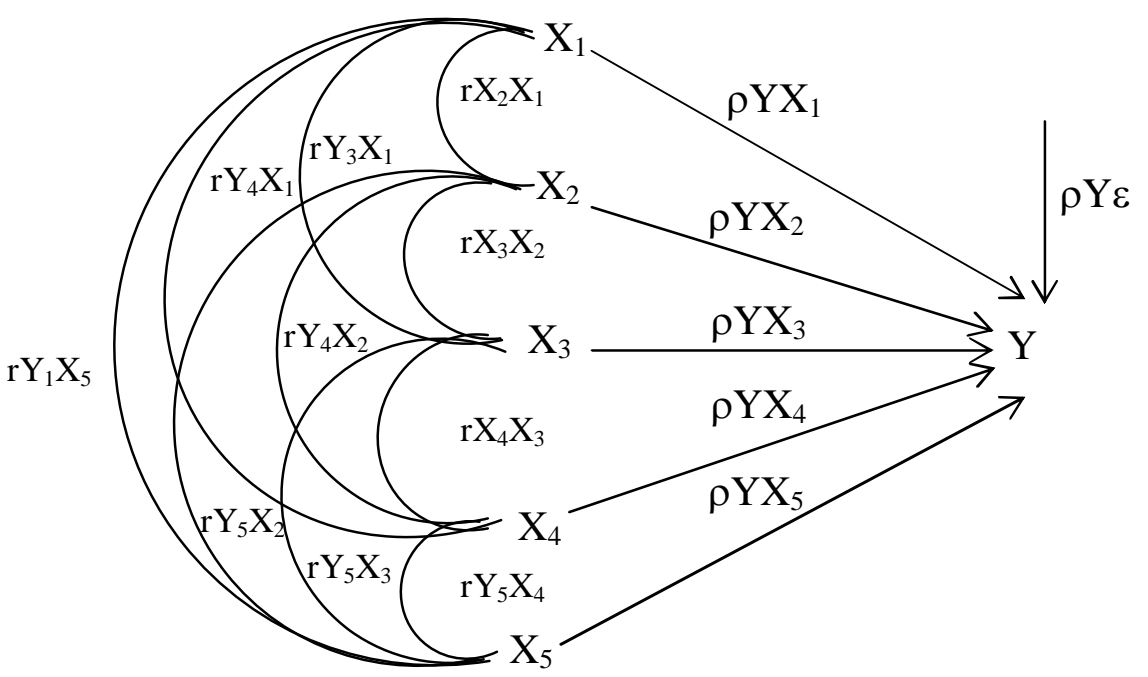

Gambar 2.3. Hubungan Struktural a nta ra variabel $\mathrm{X}_{1}, \mathrm{X}_{2}, \mathrm{X}_{3}, \mathrm{X}_{4}, \mathrm{X}_{5}$ dan $\mathrm{Y}$

Keterangan :

$\mathrm{X}_{1} \quad$ : Dimensi Tangible

$\mathrm{X}_{4} \quad$ : Dimensi Assurance

$X_{2} \quad$ : Dimensi Reliabilitas

$X_{5} \quad$ : Dimensi Emphaty

$X_{3} \quad$ : Dimensi Responsiveness

Y : Loyalitas Pelanggan

Dalam penelitian ini, ukuran sampel ditentukan berdasarkan sampel awal yang disebar, yaitu 35 kuesioner. Setelah tahap pengumpulan, kuesioner di pisahkan antara kuesioner yang lengkap dan tidak ada ragu-ragu dipihak responden dan kuesioner yang tidak lengkap dan ada keraguan dipihak responden. Terkumpul yang layak diolah adalah 30 kuesioner, sehingga a da 5 yang tidak layak. Maka proporsi kuesioner yang layak (p) adalah $\frac{30}{35}=0.86$ dan proporsi kuesioner yang tidak layak $(q)$ adalah $1-0.86=0.14$. dengan $\alpha$ sebesar 0.1 (10\%) dan e sebesar 0.05, maka persamaan Bemoulli didapat jumlah sampel minimal yang diambil adalah :

$$
\begin{aligned}
& \mathrm{n} \geq \frac{\mathrm{Z}_{\alpha / 2} p q}{e^{2}} \\
& \mathrm{n} \geq \frac{1.96 \times 0.86 \times 0.14}{(0.05)^{2}}
\end{aligned}
$$

$\mathrm{n} \geq 94.39 \cong 95$ 
Maka sa mpel minimum a da lah 95 kuesioner dan dalam penelitian ini dibulatkan ja di 100 .

\section{Pengolahan Data Penelitian}

\section{Mengukur Service quality}

Dalam perhitungan service quality yang didasarkan pada data persepsi dan harapan pelanggan, diperoleh nilai dari Service quality untuk setiap sub item (atribut), seperti disajikan dalam tabel berikut:

Tabel 3.4. Persepsi, Harapan dan Gap setiap a tribut

\begin{tabular}{|c|c|c|c|c|c|c|}
\hline NO & ATRIBUT & Persepsi & Harapan & Gap & SenQual & Kepuasan \\
\hline I & Tangibles & & & & & \\
\hline 1 & Penampilan Kemasan & 2.90 & 3.11 & -0.21 & -0.05 & $93.2 \%$ \\
\hline 2 & Penampilan Desain & 2.83 & 3.13 & -0.30 & -0.07 & $90.4 \%$ \\
\hline 3 & Penataan Produk Di Outlet & 2.83 & 3.23 & -0.40 & -0.10 & $87.6 \%$ \\
\hline 4 & Kemampuan Pelayanan SPG & 2.75 & 3.15 & -0.40 & -0.10 & $87.3 \%$ \\
\hline 5 & Petunjuk Komposisi & 3.01 & 3.54 & -0.53 & -0.13 & $85.0 \%$ \\
\hline \multirow[t]{2}{*}{6} & Petunjuk Ukuran Saji & 3.13 & 3.47 & -0.34 & -0.08 & $90.2 \%$ \\
\hline & Rata-rata & 2.91 & 3.27 & -0.36 & -0.09 & $88.9 \%$ \\
\hline II & Reliability & & & & & \\
\hline 7 & Harga Yang Di Tawarkan & 2.94 & 3.43 & -0.49 & -0.13 & $85.7 \%$ \\
\hline 8 & Rasa Yang Tersedia & 2.86 & 3.37 & -0.51 & -0.13 & $84.9 \%$ \\
\hline 9 & Kualitas \& Jaminan Mutunya & 3.16 & 3.64 & -0.48 & -0.13 & $86.8 \%$ \\
\hline 10 & Adanya Zat Tambahan (Suplemen) & 2.95 & 3.61 & -0.66 & -0.17 & $81.7 \%$ \\
\hline 11 & Kandungan Yang ada Di Susu & 3.07 & 3.58 & -0.51 & -0.13 & $85.8 \%$ \\
\hline \multirow[t]{2}{*}{12} & Ketersediaan Stock Dipasaran & 3.14 & 3.32 & -0.18 & -0.05 & $94.6 \%$ \\
\hline & Rata-rata & 3.02 & 3.49 & -0.47 & -0.12 & $86.5 \%$ \\
\hline III & Responsiveness & & & & & \\
\hline 13 & Tanggapan Ataskeluhan Produk ini & 3.15 & 3.62 & -0.47 & -0.06 & $87.0 \%$ \\
\hline 14 & Tanggapan Atas Pertanyaan Konsumen & 3.29 & 3.56 & -0.27 & -0.04 & $92.4 \%$ \\
\hline \multirow[t]{2}{*}{15} & Pelayanan Operator Bebas Pulsa & 3.33 & 3.54 & -0.21 & -0.03 & $94.1 \%$ \\
\hline & Rata-rata & 3.26 & 3.57 & -0.32 & -0.04 & $91.1 \%$ \\
\hline IV & Assurance & & & & & \\
\hline 16 & J aminan Kedaluarsa & 3.29 & 3.49 & -0.20 & -0.03 & $94.3 \%$ \\
\hline 17 & Kepastian Halal \& Ha ram & 3.19 & 3.40 & -0.21 & -0.03 & $93.8 \%$ \\
\hline \multirow[t]{2}{*}{18} & J enis Susu sesuai kebutuhan bayi & 3.31 & 3.49 & -0.18 & -0.02 & $94.8 \%$ \\
\hline & Rata-rata & 3.26 & 3.46 & -0.20 & -0.03 & $94.3 \%$ \\
\hline $\mathbf{V}$ & Emphaty & & & & & \\
\hline 19 & Tersedianya Call Center & 3.08 & 3.33 & -0.25 & -0.06 & $92.5 \%$ \\
\hline 20 & Layanan Puma Jual & 3.36 & 3.45 & -0.09 & -0.02 & $97.4 \%$ \\
\hline 21 & $\begin{array}{l}\text { Hubungan secara langsung dengan } \\
\text { produsen }\end{array}$ & 3.22 & 3.70 & -0.48 & -0.11 & $87.0 \%$ \\
\hline 22 & Hubungan Via telepon dengan produsen & 3.55 & 3.67 & -0.12 & -0.03 & $96.7 \%$ \\
\hline 23 & Penjelasan Terhadap Produk & 3.13 & 3.45 & -0.32 & -0.07 & $90.7 \%$ \\
\hline & Rata-rata & 3.27 & 3.52 & -0.25 & -0.06 & $92.8 \%$ \\
\hline
\end{tabular}

Menghitung Koefisien J alur

Tabel 3.5. J umlah Skor Va riabel X - Y

\begin{tabular}{|c|c|c|c|c|c|c|}
\hline & \multicolumn{5}{|c|}{ Kepuasan } & $\begin{array}{c}\mathbf{Y} \\
\text { (Loyalitas) }\end{array}$ \\
\cline { 2 - 6 } & $\mathbf{X}_{\mathbf{1}}$ & $\mathbf{X}_{\mathbf{2}}$ & $\mathbf{X}_{\mathbf{3}}$ & $\mathbf{X}_{\mathbf{4}}$ & $\mathbf{X}_{\mathbf{5}}$ & $\mathbf{1 8 4 0 . 8 9}$ \\
\hline Jml & $\mathbf{8 9 . 5 8}$ & $\mathbf{8 7 . 3 6}$ & $\mathbf{9 1 . 9 5}$ & $\mathbf{9 5 . 3 4}$ & $\mathbf{9 4 . 0 8}$ & $\mathbf{1 8 4 0 . 8}$ \\
\hline
\end{tabular}




\begin{tabular}{|l|l|l|l|l|l|l} 
Jkk & 81.52 & 77.61 & 85.89 & 92.68 & 90.58 & 34862 \\
\hline
\end{tabular}

Uji Signifika nsi Koefisien J a lur

a. Secara Keselunuhan

Pengujian secara keselunuhan ini menggunakan Hipotesa seba gai berikut :

$\mathrm{H}_{0}: \rho_{\mathrm{yx}}=\rho_{\mathrm{y} \times 2}=\ldots \ldots . . .=\rho_{\mathrm{y} \times \mathrm{k}}=0$

$\mathrm{H}_{1}$ : Sekurang-kurangnya a da sebuah $\rho_{y \times k} \neq 0 ; k=1,2,3 \ldots .5$

Dari perhitungan diperoleh $F_{\text {hitung }}(2.572)>F_{\text {tabel }}$ (2.37), maka keputusannya adalah tolak $H_{0}$. artinya semua dimensi kepuasan pelanggan secara serempak benpengaruh terhadap loyalitas pelanggan.

b. Secara Individu

Pada pengujian secara individu ini dilakukan hipotesa seperti berikut :

$\mathrm{H}_{0}: \rho_{\mathrm{yxk}}=0$

$H_{1}: \rho_{y x i} \neq 0 ; k=1,2,3,4,5$

Ta bel 3.8. Pengujian Individual

\begin{tabular}{|c|c|c|c|}
\hline Variabel & tabel & Thitung & Keputusan \\
\hline $\begin{array}{c}\mathrm{X}_{1} \\
\text { Tangible }\end{array}$ & 1.671 & 1.989 & $\begin{array}{l}\text { Tolak Ho } \\
\text { Kepuasan Pelanggan terhadap dimensi Tangible berpenganuh } \\
\text { terhadap loyalitas pelanggan }\end{array}$ \\
\hline $\begin{array}{c}\mathrm{X}_{2} \\
\text { Reliabilitas }\end{array}$ & 1.671 & 3.351 & $\begin{array}{l}\text { Tolak Ho } \\
\text { Kepuasan Pela nggan terhadap dimensi Reliabilitas berpenga ruh } \\
\text { terhadap loyalitas pelanggan }\end{array}$ \\
\hline $\begin{array}{l}\mathrm{X}_{3} \\
\text { Responsive } \\
\text { ness }\end{array}$ & 1.671 & 2.336 & $\begin{array}{lll} & \text { Tolak Ho } & \\
\text { Kepuasan Pelanggan terhadap dimensi } & \text { Responsiveness } \\
\text { berpenganuh terhadap loyalitas pelanggan } & \end{array}$ \\
\hline $\begin{array}{c}\mathrm{X}_{4} \\
\text { Assurance }\end{array}$ & 1.671 & 3.379 & $\begin{array}{l}\text { Tolak Ho } \\
\text { Kepuasan Pelanggan terhadap dimensi Assurance berpenga ruh } \\
\text { terhadap loyalitas pelanggan }\end{array}$ \\
\hline $\begin{array}{c}\mathrm{X}_{5} \\
\text { Emphaty }\end{array}$ & 1.671 & 3.356 & $\begin{array}{l}\text { Tolak Ho } \\
\text { Kepuasan Pelanggan terhadap dimensi Emphaty berpengaruh } \\
\text { terhadap loyalitas pelanggan }\end{array}$ \\
\hline
\end{tabular}

\section{Mengukur Pengaruh Langsung dan Tidak Langsung}

Tabel 3.9. Pengaruh Langsung \& tidak langsung dari Kepuasan (dimensi Tangible) terhadap loya litaspelanggan

\begin{tabular}{|c|c|c|c|}
\hline \multicolumn{2}{|c|}{ Penga ruh Langsung \& Tidak Langsung X1 } & \multicolumn{2}{|c|}{ Besamya Kontribus } \\
\hline $\mathrm{X} 1$ & Pyx1.Pyx1 & 0.0458 & $4.58 \%$ \\
\hline Melalui X2 & $\operatorname{Py}(x 1 \times 2)=P y \times 1 . n 1 \times 2 P y x 2$ & 0.0325 & $3.25 \%$ \\
\hline Melalui X3 & $\operatorname{Py}(x 1 \times 3)=$ Pyx1. $n 1 \times 3$ Pyx3 & 0.0029 & $0.29 \%$ \\
\hline Melalui X4 & $\operatorname{Py}(x 1 \times 4)=$ Pyx1. $r 1 \times 4$ Pyx4 & 0.0073 & $0.73 \%$ \\
\hline Melalui X5 & $\operatorname{Py}(x 1 \times 5)=$ Pyx1. $x 1 \times 5$ Pyx5 & 0.0106 & $1.06 \%$ \\
\hline & tal Penga ruh X1 temadap $Y$ & 0.0991 & $9.91 \%$ \\
\hline
\end{tabular}


Tabel 3.10. Pengaruh Langsung \& tidak langsung dari Kepuasan (dimensi Reliabilitas) terhadap loya litaspelanggan

\begin{tabular}{|c|c|c|c|}
\hline \multicolumn{2}{|c|}{ Penga ruh Langsung $\&$ Tidak Langsung X2 } & \multicolumn{2}{|c|}{ Besa mya Kontribusi } \\
\hline $\mathrm{X} 2$ & Pyx2.Pyx2 & 0.1544 & $15.44 \%$ \\
\hline Melalui X1 & Py $(x 2 x 1)=$ Pyx2. $n 2 x 1 P y x 1$ & 0.0325 & $3.25 \%$ \\
\hline Melalui X3 & $\operatorname{Py}(x 2 \times 3)=$ Pyx2. $1 \times 2 \times 3$ Pyx3 & 0.0177 & $1.77 \%$ \\
\hline Melalui X4 & $\operatorname{Py}(x 2 \times 4)=P y \times 2 . n 2 x 4 P y x 4$ & 0.0202 & $2.02 \%$ \\
\hline Melalui X5 & $\operatorname{Py}(\times 2 \times 5)=P y \times 2.1 \times 2 \times 5 P y x 5$ & 0.0254 & $2.54 \%$ \\
\hline & tal Penga ruh $X 2$ terhadap $Y$ & 0.2503 & $25.03 \%$ \\
\hline
\end{tabular}

Tabel 3.11. Pengaruh Langsung \& tidak langsung dari Kepuasan (dimensi Responsiveness) terhadap loya litaspelanggan

\begin{tabular}{|c|c|c|c|}
\hline \multicolumn{2}{|c|}{ Penga ruh Langsung $\&$ Tidak Langsung X3 } & \multicolumn{2}{|c|}{ Besa mya Kontribusi } \\
\hline X3 & Pyx3.Pyx3 & 0.0193 & $1.93 \%$ \\
\hline Melalui X1 & $\operatorname{Py}(x 3 \times 1)=$ Pyx3. $n \times 3 \times 1 P y x 1$ & 0.0029 & $0.29 \%$ \\
\hline Melalui X2 & $\operatorname{Py}(\times 3 \times 2)=$ Pyx3. $1 \times 3 \times 2$ Pyx2 & 0.0177 & $1.77 \%$ \\
\hline Melalui X4 & $\operatorname{Py}(\times 3 \times 4)=$ Pyx3. $1 \times 3 \times 4$ Pyx4 & 0.0047 & $0.47 \%$ \\
\hline Melalui X5 & $\operatorname{Py}(\times 3 \times 5)=$ Pyx3. $1 \times 3 \times 5$ Pyx5 & 0.0052 & $0.52 \%$ \\
\hline & otal Penga ruh X3 terha dap $Y$ & 0.0499 & $4.99 \%$ \\
\hline
\end{tabular}

Tabel 3.12. Pengaruh Langsung \& tidak langsung dari Kepuasan (dimensi Assurance) terhadap loya litas pelanggan

\begin{tabular}{|c|c|c|c|}
\hline \multicolumn{2}{|c|}{ Pengaruh Langsung $\&$ Tidak Langsung X4 } & \multicolumn{2}{|c|}{ Besamya Kontribusi } \\
\hline $\mathrm{X} 4$ & Pyx4.Pyx4 & 0.0372 & $3.72 \%$ \\
\hline Melalui X1 & $\operatorname{Py}(x 4 \times 1)=$ Pyx4. $1 x 4 \times 1 P y x 1$ & 0.0073 & $0.73 \%$ \\
\hline Melalui X2 & $P y(x 4 \times 2)=P y x 4.1 \times 4 \times 2 P y \times 2$ & 0.0202 & $2.02 \%$ \\
\hline Melalui X3 & $\operatorname{Py}(x 4 \times 3)=$ Pyx4. $1 \times 4 \times 3$ Pyx3 & 0.0047 & $0.47 \%$ \\
\hline Melalui X5 & $P y(x 4 \times 5)=P y x 4.1 \times 4 \times 5 P y \times 5$ & 0.0084 & $0.84 \%$ \\
\hline & Total Penga ruh X4 terha dap $Y$ & 0.0778 & $7.78 \%$ \\
\hline
\end{tabular}

Tabel 3.13. Pengaruh Langsung \& tidak langsung dari Kepuasan (dimensi Emphaty) terhadap loya litaspelanggan

\begin{tabular}{|c|c|c|c|}
\hline \multicolumn{2}{|c|}{ Penga ruh Langsung \& Tidak Langsung X5 } & \multicolumn{2}{|c|}{ Besamya Kontribusi } \\
\hline$\times 5$ & Pyx5.Pyx5 & 0.0199 & $1.99 \%$ \\
\hline Melalui X1 & $\operatorname{Py}(x 5 \times 1)=P y x 5.1 \times 5 \times 1 P y x 1$ & 0.0106 & $1.06 \%$ \\
\hline Melalui X2 & $P y(x 5 \times 2)=P y x 5.1 \times 5 \times 2 P y x 2$ & 0.0254 & $2.54 \%$ \\
\hline Melalui X3 & $P y(x 5 \times 3)=P y x 5.1 \times 5 \times 3 P y x 3$ & 0.0052 & $0.52 \%$ \\
\hline Melalui X4 & $P y(x 5 \times 4)=P y \times 5.1 \times 5 \times 4 P y x 4$ & 0.0084 & $0.84 \%$ \\
\hline & Total Penga ruh $\mathrm{X} 5$ terha dap $\mathrm{Y}$ & 0.0695 & $6.95 \%$ \\
\hline
\end{tabular}

Secara lengkap hasil perhitungan pengaruh langsung dan tidak langsung dari dimensidimensi kepuasan pelanggan terhadap loyalitas pelanggan terangkum dalam tabel 3.14. dan gambar 3.2. dibawah ini : 
Tabel 3.14. Rangkuman Pengaruh langsung \& tidak Langsung dari dimensi Kepuasan terhadap Loyalitaspelanggan

\begin{tabular}{|c|c|c|c|c|c|c|c|c|}
\hline \multirow{3}{*}{ Dimensi } & \multicolumn{7}{|c|}{ Penga ruh va riabel independen terhadap dependen } & \multirow{3}{*}{$\begin{array}{c}\text { Pengaruh } \\
\text { Total }\end{array}$} \\
\hline & \multirow[b]{2}{*}{ Langsung } & \multicolumn{6}{|c|}{ Tidak langsung } & \\
\hline & & Tangible & Reliabilitas & Responsive & Assurance & Emphaty & Total & \\
\hline Tangible & 0.0458 & & 0.0325 & 0.0029 & 0.0073 & 0.0106 & 0.0533 & 0.0991 \\
\hline Reliabilitas & 0.1544 & 0.0325 & & 0.0177 & 0.0202 & 0.0254 & 0.0959 & 0.2503 \\
\hline Responsiveness & 0.0193 & 0.0029 & 0.0177 & & 0.0047 & 0.0052 & 0.0305 & 0.0499 \\
\hline Assurance & 0.0372 & 0.0073 & 0.0202 & 0.0047 & & 0.0084 & 0.0406 & 0.0778 \\
\hline Emphaty & 0.0199 & 0.0106 & 0.0254 & 0.0052 & 0.0084 & & 0.0496 & 0.0695 \\
\hline \multicolumn{7}{|c|}{ Penga ruh $X 1, X 2, X 3, X 4, X 5$ terha dap $Y$} & & 0.5466 \\
\hline \multicolumn{7}{|c|}{ Penga ruh Variabel lain (e) terha dap Y } & & 0.4534 \\
\hline
\end{tabular}

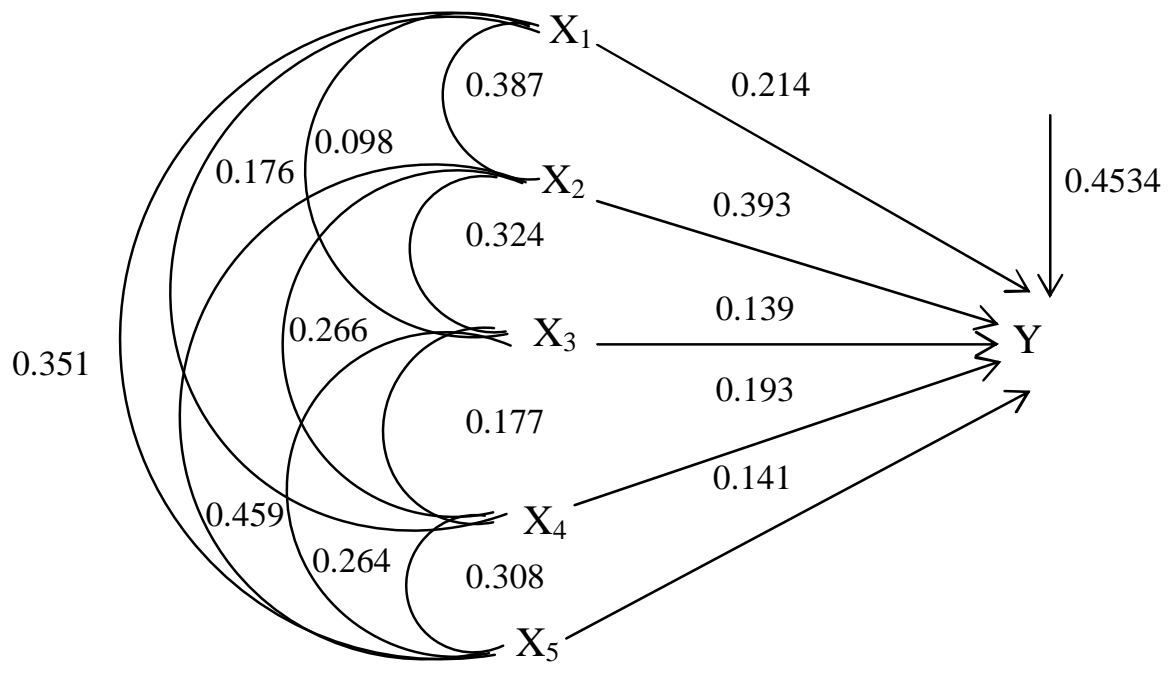

Gambar 3.2. Hubungan Struktural antara va riabel $\mathrm{X}_{1}, \mathrm{X}_{2}, \mathrm{X}_{3}, \mathrm{X}_{4}, \mathrm{X}_{5}$ dan $\mathrm{Y}$

\section{Senvice Quality dimensi Tangible}

Pa da dimensi ini, konsumen menila i bahwa a tribut bentuk desa in kemasan, bahan kemasan, penataan produk di outlet, kemampuan SPG, Petunjuk ukuran saji \& ukuran komposisi yang melekat pada produk susu bayi ini belum sesuai dengan harapan konsumen. Hal ini dapat dilihat dari nilai Service quality yang mash bemilai negatif yang diberikan pada item-item pada atribut tersebut. Pada dimensi ini, apa yang diharapka pelanggan dari produk susu bayi ini memiliki nilai terbaik pada penampilan kemasan $(-0.05)$, sedangkan yang belum memuaskan bagi konsumen adalah item petunjuk komposisi $(-0.13)$

PT.X memproduksi susu bayi dalam dua bentuk kemasan yaitu kaleng (platinum) dan kotak (kardus). Konsumen sangat antusias dengan produk yang membagi kemasannya menjadi dua. Kemasan ini juga menandai sebagai bagian dari segmentasi yang berbeda dari PT. X. 
Produk dengan kemasan kardus (kotak) adalah produk dengan ukuran kemasan isi dimulai dari keamasan besar sampai ukuran sangat kecil (harga tejangkau). Sehingga konsumen dengan tingkat ekonomi menengah kebawah dapat menggunakan produk susu dengan kemasan kotak ini. Sementara kemasan kaleng (platinum) bagi mereka dengan tingkat ekonomi menengah keatas, mengingat pada kemasan ini hanya tersedia pada ukuran yang medium ke atas dengan harga sedikit mahal. Item dimensi ini (bentuk kemasan) terbukti memberikan kepuasan konsumen tertinggi sebesar 93.2\%. yang perlu segera mendapat perhatian PT. X untuk diperbaiki adalah petunjuk komposisi (85\%). Konsumen beranggapan semua jenis susu bayi selalu menyediakan komposisi kandungan produk susu bayi ini. Sehingga berakibat konsumen mengabaikan keadaan komposisi ini, yang untuk selanjutnya menjadikan item petunjuk komposisi kurang begitu penting bagi konsumen

\section{Senvice Quality dimensi Reliabilitas}

Konsumen susu bayi menilai bahwa dimensi ini merupakan dimensi terpenting dalam memberikan produk yang bemilai dan bemutu, dengan memberikan bobot $26 \%$ relatif terhadap total. Tingkat kepuasan konsumen untuk dimensi ini adalah $86.5 \%$ yang dinilai sebagai dimensi yang paling belum memenuhi keinginan dan harapan (ekspektasi) konsumen. Pada dimensi ini, konsumen meniali bahwa kemampuan PT.X dalam memberikan keterandalan produk susu bagi konsumen belum sesuai harapan konsumen. Nilai service qua lity bemilai negatif untuk item-itempa da a trib ut tersebut menunjukan bahwa produk susu bayi dari PT. X ini masih di bawah apa yang diinginkan oleh konsumen. Untuk dimensi ini, hal yang bagi konsumen dinilai memberikan service quality yang terbaik berasal dari item pertanyaan ketersediaan stock dipasaran (-0.05).

\section{Senvice Quality dimensi Responsiveness}

Tingkat kepuasan pelanggan untuk dimensi ini adalah $91.1 \%$ dan mempunyai bobot $13 \%$ relatif penting bila dilihat dari total keselunuhan Senvice quality. Pada dimensi ini, konsumen menilai produk susu yang diberikan belum sesuai harapan mereka. Ini terlihat dari nilai service quality yang bemilai negatif yang diberikan untuk item-item pada atribut tersebut (tanggapan atas produk susu ini, atas pertanyaan konsumen, pelyanan operator bebas pulsa). Untuk dimensi ini, item yang bagi konsumen memiliki nilai service quality terbaik berasal dari item pelayanan bebas pulsa $(-0.03)$ sedangkan yang paling buruk, ya itu belum memuaskan bagi konsumen adalah item tanggapan ataskeluhan produk ini(-0.06). 


\section{Senice Quality dimensi Assurance}

Pada dimensi Assurance (jaminan) ini kepuasan konsumen yang dihasilkan a dalah sebesar 94.3\%, nilai ini memiliki tingkat kepuasan terbesar jika dibandingkan dengan 4 dimensi yang lainnya. Sedangkan bobot kepentingan dimensi ini terhadap keselunuhan service quality adalah $13 \%$. Konsumen dari produk susu PT. $\mathrm{X}$ ini menilai bahwa jaminan halal $\&$ haram, kepastian kedaluarsa serta jaminan kesesuaian produk susu ini dengan yang dibutuhkan oleh bayi (Assurance) belum sesuai dengan harapan konsumen. Hal ini dapat dilihat dari nilai service quality masih bemilai negatif yang diberikan untuk item-item pada atribut tersebut. Untuk dimensi ini item yang paling memberikan nilai sevice quality tebaik bagi konsumen adalah kepastian jenis susu sesuai kebutuhan bayi (-0.02) sedangkan yang kurang dapat memberikan kepuasan bagi konsumen adalah item jaminan halal \& haram, kepastian kedaluarsa masing-masing bemilai (-0.03).

\section{Senvice Quality dimensi Emphaty}

Tingkat kepuasan konsumen untuk dimensi Emphaty ini adalah $92.8 \%$, sementara bobot kepentingan dimensi ini terhadap keselunuhan Service Quality adalah 22\%. Konsumen produk susu PT. SangHiang Perkasa menilai bahwa atribut tersedianya call center, layanan puma jual, hubungan secara langsung dengan produsen, hubungan via telepon dengan produsen dan penjelasan terhadap produk susu ini (emphaty) belum sesuai dengan harapan konsumen untuk suatu produsen susu yang terbaik. Hal ini dapat dilihat dari nilai Service Quality yang masih bemilai negatif yang diberikan untuk item-item pada atribut tersebut. Untuk dimensi ini, bagian dari produk susu yang bagi konsumen dinilai memberikan Service Quality terbaik berasal dari item layanan puma jual (-0.02) sedangkan yang paling belum memuasakan bagi konsumen adalah item hubungan secara langsung dengan produsen (-0.11)

Penerapan model Service Quality banyak diterapkan di berbagai area layanan jasa maupun produk (barang). Sebagian besar penelitian tersebut memodifikasi Service Quality untuk disesuaikan dengan area dimana Service Quality dipergunakan. Sejumlah penelitian mengoreksi Service Quality dan menyimpulkan adanya beberapa kekurangan dari model tersebut. Menurut Caman (1990), Babakus dan Boller (1992), serta Cronin dan Taylor (1994) dala m Pa witra (1998), kekurangan Service Quality antara la in terdapat pada hal :

a. Konseptualisasi

Pengukuran Service Quality adalah prilaku, bukanlah paradigma dari kepuasan (satisfaction), sehingga Service Quality fungsi dari Performance. 


\section{b. Dimensi}

Banyaknya dimensi Service Quality yang digunakan bergantung pada jenis organisasi yang akan menerapkan model tersebut.

c. Operasional

Adanya kesulitan dalam penga mbilan data ekspektasi pada organisa si tertentu.

Meskipun demikian model Service Quality telah memberikan kontribusi yang penting dan berharga dalam pengukuran Service Quality yang dirasa kan oleh konsumen (pelanggan).

\section{Penganuh Kepuasan Konsumen Terhadap Loyalitas pelanggan}

Proporsi hipotesis yang diajukan selunuhnya dapat diterima sebab berdasarkan hasil pengujian koefisien jalur dari $X_{1}, X_{2}, X_{3}, X_{4}$ dan $X_{5}$ terhadap $Y$ secara statistik signifikan. Sehingga kepuasan konsumen pada dimensi-dimensi Senvice Quality yang meliputi Tangible, Reliability, Responsiveness, Assurance \& Emphaty secara individual dan serempak (parsial) berpenga ruh terhadap pembentukan loyalitas konsumen.

\section{Pengaruh Langsung, Penganuh tidak Langsung dan Penganuh Total Dimensi-dimensi Service Quality Konsumen Terhadap Loyalitas Konsumen}

Kepuasan konsumen terhadap kemampuan menghasilkan produk yang sesuai yang dijanjikan, secara teliti dan dapat diandalkan yang diberikan oleh PT.X (dimensi Reliability) merupakan faktor yang paling dominan dalam memberikan kontribusi pengaruh langsung terhadap loyalitas konsumen, yaitu sebesar $15.4 \%$, artinya untuk setiap 10000 orang terdapat 1540 orang konsumen yang loyal karena merasa puas terhadap kemampuan meng ha silkan produk sesua i yang dijanjikan, seca ra teliti dan dapat dianda lkan dari PT. X. Kemampuan menghasilkan produk yang sesuai yang dijanjikan yang dimaksud dalam dimensi Reliability meliputi harga yang ditawarkan, rasa yang tersedia, kualitas \& jaminan mutunya, adanya suplemen pada produk susu bayi, kandungan yang terdapat pada susu bayi dan ketersediaan stok dipasaran (distribusi). Tingginya tingkat kepuasan konsumen terhadap kemapuan menghasilkan produk sesuai dengan yang dijanjikan telah memberikan kontribusi terhadap pembentukan loyalitas konsumen. Item-item reliability telah secara langsung mempengaruhi konsumen untuk melakukan pembelian ulang, tidak terpengaruh daya tarik pesaing dan selanjutnya konsumen akan merekomendasikan pada orang lain untuk melakukan pembelian produk susu bayi ini. 
Kontribusi kepuasan dimensi Reliability terhadap loyalitas konsumen ini sesuai dengan Levitt (1987) yaitu tugas pemasar suatu produk/jasa adalah meyakinkan pembeli terhadap ketidakpastian akan produk tersebut (probabilistik goods). Konsumen tidak dapat menilai suatu produk sebelum mereka merasakan atau menggunakan produk/jasa tersebut. Oleh karenanya untuk masyarakat mengeliminasi ketidakpastian, konsumen akan memperhatikan atribut pada produk tersebut yang menjadikan produk tersebut lebih handal dari produk la in yang sejenis.

Kepuasan konsumen terhadap dimensi responsif (responsiveness) yang diberikan oleh PT. X menupakan faktor yang paling rendah dan sedikit pengaruh langsungnya terhadap pembentukan loya lita s konsumen, ya itu sebesar $1.93 \%$. Artinya setiap 10000 orang konsumen produk susu dari PT. X hanya 193 konsumen yang loyal ka rena puas terhadap respon yang diberikan oleh produk susu bayi ini. Rendahnya kontribusi dimensi Responsiveness ini terhadap loyalitas konsumen disebabkan rendahnya kepuasan konsumen terhadap produk susu bayi dari PT. X. Konsumen tetap setia menggunakan susu bayi ini bukan karena faktor responsifnya pihak produsen tetapi oleh karena faktor lainnya. Artinya produsen perlu memperhatikan mengingat dimensi ini (Responsiveness) juga memiliki nilai bobot kepentingan terendah. Apabila konsumen merasa puas terhadap dimensi ini, maka dapat dipastikan akan besar seka li dukungannya terha dap pembentukan loyalitas pelanggan.

Tabel 4.1. Pengaruh Langsung dimensi-dimensi kepuasan terhadap Loyalitas konsumen (diunutkan berd a sar nilai tertinggi pengaruhnya)

\begin{tabular}{|c|r|r|}
\hline \multicolumn{1}{|c|}{ Rangking } & \multicolumn{1}{|c|}{ Dimensi Kepuasa Pelanggan } & Besar penganuh Langsung \\
\hline \hline 1 & $\begin{array}{l}\text { Kemampuan menghasilkan produk yang sesuai yang } \\
\text { dijanjikan, secara teliti dan dapat diandalkan (Relia bilitas) }\end{array}$ & $15.44 \%$ \\
\hline 2 & Segala Fasilitas Fisik yang nampak dimata Konsumen (Tangible) & $4.58 \%$ \\
\hline 3 & $\begin{array}{l}\text { Kepastian isi produk susu ini, bebas dari efek samping yang } \\
\text { buruk bagi bayi (Assurance) }\end{array}$ & $3.72 \%$ \\
\hline 4 & $\begin{array}{l}\text { Perhatian dan produsen terhadap kebutuhan pelanggan } \\
\text { konsumen (Emphaty) }\end{array}$ & $1.99 \%$ \\
\hline 5 & $\begin{array}{l}\text { Kesediaan \& kesiapan untuk konsumen dan memberikan } \\
\text { kemudahan dalam pemuasan konsumen (Responsiveness) }\end{array}$ & $1.93 \%$ \\
\hline
\end{tabular}

Ta bel 4.2. Penga ruh Total dimensi-dimensi kepuasan terha dap Loya lita s konsumen (diuntkan berda sar nilai tertinggi penga ruhnya)

\begin{tabular}{|c|l|r|}
\hline Rangking & \multicolumn{1}{|c|}{ Dimensi Kepuasa Pelanggan } & Besar penganuh Langsung \\
\hline 1 & $\begin{array}{l}\text { Kemampuan meng hasilkan produk yang sesuai yang } \\
\text { dija njikan, secara teliti dan dapat diandalkan (Reliabilitas) }\end{array}$ & $25.03 \%$ \\
\hline 2 & $\begin{array}{l}\text { Segala Fa silitas Fisik yang nampak dimata Konsumen } \\
\text { (Tangible) }\end{array}$ & $9.91 \%$ \\
\hline 3 & $\begin{array}{l}\text { Kepastian isi produk susu ini, bebas dari efek samping yang } \\
\text { buruk bagi bayi (Assurance) }\end{array}$ & $7.78 \%$ \\
\hline 4 & $\begin{array}{l}\text { Perhatian dan produsen terhadap kebutuhan pelanggan } \\
\text { konsumen (Emphaty) }\end{array}$ & $6.95 \%$ \\
\hline
\end{tabular}




\section{KESIMPULAN}

Berdasarkan analisis hasil pengolahan data, dapat dirumuskan beberapa kesimpulan sebagai berikut :

1. Konsumen Susu bayi dari PT. X ini menila i Service Quality yang mereka terima masih belum memenuhi harapan mereka. Hal ini da pat dilihat dari nilai yang didapat dari hasil pengolahan data pada semua dimensi Service Quality. Nilai total dari Service Quality PT. X sebesar (-0.34), dimana nilai Senvice Quality terbaik ada pada dimensi Assurance (0.03), kemudian dimensi Responsiveness (-0.04), disusul dimensi Emphaty $(-0.06)$, kemudian dimensi Tangible (-0.09) dan terakhir sebagai dimensi terendah adalah Relia bility (-0.12).

2. Belum sesuainya antara apa yang diinginkan konsumen dengan apa yang diberikan PT.X pada susu bayi ini, menunjukan bahwa masih adanya gap antara nilai harapan (ekspektasi) dan nilai persepsi dari konsumen. Gap terbesar terdapat pada dimensi Reliability (-0.47) disusul dimensi Tangible (-0.36) kemudian dimensi Responsiveness (-0.32) disususul dimensi Emphaty (-0.25) dan dimensi yang memiliki gap terendah adalah Assurance (-0.20).

3. Untuk kepuasan konsumen perlu dic emmati dalam usaha untuk meningkatkan kepuasan konsumen pada dimensi-dimensi Service Quality maka diperlukan prioritas perbaikan dimulai dari dimensi reliability (0.865), disusul dimensi Tangible (0.889) kemudian dimensi Responsiveness (0.911) selanjutnya dimensi Emphaty (0.928) yang tera khir prioritasnya ada lah dimensi Assurance (0.943).

4. Dimensi keterandalan (Reliability) memiliki nilai bobot kepentingan tertinggi yang artinya dinilai paling penting oleh konsumen, memiliki nilai Service Quality dan nilai kepuasan yang paling rendah. Sedangkan jaminan kedaluarsa, kepastian halal \& haram serta jenis susu sesuai dengan kebutuhan bayi (dimensi Assurance) memiliki nilai Service Quality paling tinggi walaupun belum sepenuhnya sesuai dengan harapan konsumen karena nila inya masih negatif.

5. Service Quality pada dimensi Assurance yang dinilai memberikan nilai Service Quality terbaik berasal dari item jenis susu bayi sesuai dengan yang dibutuhan bayi (jaminan dari tidak membahayakan pertumbuhan bayi) (-0.02) disusul pada nilai yang sama pada item jaminan kedaluarsa dan jaminan halal dan haram (-0.03).

6. Dimensi Responsiveness, bagian item yang bagi konsumen dinilai memberikan nilai Service Quality terbaik berasal dari item pelayanan operator bebas pulsa (-0.03) disusul item tanggapan atas pertanyaan konsumen $(-0.04)$ dan item terendah adalah tanggapan ataskeluhan produk susu ini (-0.06). 
7. Dimensi Emphaty, bagian item yang bagi konsumen dinilai memberikan nilai Service Quality terbaik berasal dari item layanan puma jual (-0.02), disusul hubungan via telepon dengan produsen (-0.03), kemudian yang paling belum memuaskan adalah hubungan secara langsung dengan produsen (-0.11).

8. Dimensi Tangible, bagian item yang bagi konsumen dinilai memberikan nilai Service Quality terbaik berasal dari item penampilan kemasan (-0.05) dan yang dinilai paling belum memua skan adalah item petunjuk komposisi (-0.13).

9. Dimensi Reliability, bagian item yang bagi konsumen dinilai memberikan nilai Service Quality terbaik berasal dari item ketersediaan stok di pasaran (-0.05). sedangkan yang dinilai paling belum memuaskan konsumen adalah item adanya zat tambahan (suplemen) sebesar -0.17 .

10. Proporsi hipotesis yang diajukan selunuhnya dapat diterima sebab berdasarkan hasil pengujian koefisien jalur dari $X_{1}, X_{2}, X_{3}, X_{4}$, dan $X_{5}$ terhadap $Y$ secara sta tistik signifikansi. Yaitu semua dimensi kepuasan konsumen (Tangible, Reliability, Responsiveness, Assurance dan emphaty) berpengaruh terha dap loyalitas konsumen.

11. Untuk mencapai loyalitas konsumen, perlu diperhatikan dan diprioritaskan perbaikan yang dimulai dari dimensi Responsiveness, Emphaty, Assurance, tangible dan Reliability.

12. Kepuasan konsumen terhadap Kemampuan menghasilkan produk yang sesuai yang dijanjikan, secara teliti dan dapat diandalkan dari PT.X (Reliability) merupakan faktor yang paling dominan dalam memberikan kontribusi pengaruh langsung terhadap loyalitas konsumen. Sedangkan kepuasan konsumen dari Kesediaan \& kesiapan untuk konsumen dan memberikan kemudahan dalam pemuasan konsumen (Responsiveness) merupakan faktor yang paling sedikit berpengaruh langsung terhadap pembentukan loya litas konsumen.

13. Kepuasan konsumen pada dimensi Tangible, Reliability, Responsiveness, Assurance dan emphaty secara bersama-sama berpengaruh terhadap loyalitas konsumen (54.66\%). Sedangkan pengaruh variabel-variabel lain diluar kepuasan pada Tangible, Reliability, Responsiveness, Assurance dan emphaty terhadap loyalitas (45.34\%).

\section{DAFTAR PUSTAKA}

Anonymous. 2008. servqual, (http://id.wikipedia .org/wiki/Servqual), dia kses 5 0ktober 2009). Ariani, Do rothea. 1999. Manajemen Kualitas. Edisi1, Universitas Atmaja ya, Yogyakarta. Ferdinand, Agusty, 2002 Struc tural Equation Modelling Dalam Penelitian

Manajemen, Fakultas Ekonomi Undip,Semarang, Mutma inah, 2004, “Penentuan Faktor yang Mempenga ruhi Siswa SMU Dalam Memilih Skolah dan Pengaruh Terha dap Kualitas Pendidikan di SMU yang a da di Surabaya Selatan", Tugas Akhir, J unusan Teknik Industri, ITATS. 
Pa rasuraman, Valarie A. Zeithamls dan Leonard L. Bemy

R. Lerbin R. Aritonang, 2005, “Kepuasan Pelanggan”, PTGramedia Pustaka Uta ma, J akarta.

Sugiyono, Prof. Dr, 2005, "Sta tistika untuk Penelitian", ALFABETA, Bandung.

Tjiptono Fandy dan Chandra Gregorius, 2005, "Service, Qualty\& Satification", ANDI, Yogya karta.

Temesh.1996. Customer Value of Customer Satisfaction Specification. NewYork

Preatice Hall. 